\title{
THE FUTURE OF CITIES
}

\author{
A. RAHMANI \\ School of Design and Construction, Washington State University, USA.
}

\begin{abstract}
For the first time in history the call to envisioning the future is more than a mere matter of fantasy. Up until now the look ahead had little going for it than science fiction. But the sustainability movement changed all that and made it part of our concerns today the agenda to ensure for a healthy and viable future tomorrow. It is not sure if the concern was and remains to be one about future generations as much as it is about the realization that even within one's own lifetime things might deteriorate significantly if we donot care for the wellbeing of our places, especially when life expectancy is now 10 years lengthier than it was just 50 years ago. Cities play a strong role in envisioning and developing this future, not the least because they help conserve resources while also serving as engines for economic and social growth. How will they fulfil that role is the topic of this paper, examining, among other things, the way recent data-harvesting technologies may lead us in the right direction. Keywords: Cities, data harvesting, future, urban development.
\end{abstract}

\section{INTRODUCTION}

Speculation about the future of the city has been going on for some time now and especially since the rise of the industrial revolution. Having attracted, or more likely coerced, the rural worker to the centre to work in the ever more efficient and more economically rewarding factory, the city declined just as soon as it flourished. Industrial progress moved so quickly it outpaced the city's capacity to find an appropriate match for it in housing and infrastructure.

The first to react were the communitarians, led by Robert Owen in Scotland and Charles Fourier in France. So appalled by the poverty of the rising metropolis, aesthetic as well as social, they wanted nothing to do with it. They sought their own self-organized and self-sufficient $t$ enclaves, gated communities of sorts that can restore to the human condition at least a modicum of equality and a fair access to happiness. Their version of society was less based on a structure of hierarchy, boss and labourer, and more on an open ended involvement in everyday life, including raising children and building a world [1].

The visionaries of the Columbian World Exposition of 1893 had similar concerns, namely that the city, in this case particularly the American city, had so deteriorated something drastic had to happen to save it. But rather than abandon it, they wanted to reconstitute it from within, scarp the architecture that was there and replace it with something new, something more coherent than what was there before. Lacking another model by which to work they defaulted to the European Beaux Arts one with its axial planning and formal hierarchies, borrowing equally from Rome as from Paris. The grand boulevard, the ornate façade and even the lagoon were seen as the mark of a great civilizing city and the agents by which a place can and should be unified [2].

The struggle for the good city hasnot ebbed since, perennially finding expression in various forms, some biasing the centre others the edge and some in between. Ebenezer Howard and Le Corbusier both wrote books within 20 or 30 years of each other around the turn of the 19/20th century, urging us to not give up on the city but to rethink it in a different guise, as the city of 'tomorrow' with features that would solve the mess that it had seen by their current day time. Howard [3] focused on integrating country and town in the manner of concentric circles, alternating between one and the next, while Le Corbusier sought to create in his city a match for the modern day schedule, indeed 
organize it to follow in lockstep the manner with which the division of labour had come to structure work and life itself.

There were others, each unique and different in its own special way. But as divergent as these future prospects for the city were, they all shared one thing and that is the desire to locate the human at the centre of the good life, catering to his or her haptic and corporeal connections with the world and specifically the contexts in which that person lives and works. Of particular importance is the relationship between body and space as defined by physical infrastructure - buildings, streets, parks and the like - where scale and perspective are in constant play, contracting and expanding with every move of the body in space. This is how William Whyte and Kevin Lynch made a carrier for themselves, by studying the degree to which urban spaces succeed or fail based on the position of the body or bodies in them. In his 70s book on The Social Life of Small Urban Spaces, Whyte examines city spaces from the way people use them, judging them, not based on some institutionalized aesthetic criteria but on the number of people who use them. New Yorkers love to use their plazas, he observes, but not equally. 'When we rated plazas according to the number of people sitting on them at peak time, there was a very wide range...,' he puzzled. 'How Come?' [4] he asked, going on of course to find out why in the rest of the book.

Today and for the past 20 or so years, the 'New Urbanists' have picked up a similar gauntlet, seeking to return the American city to a modicum of coherence and respectability, where the human can once again be compelled to live a life of responsibility and action. New Urbanism, according to the website run by the Congress for the New Urbanism 'offers a way to create enduring places of diversity and character..., where people can 'walk to stores, work, schools and places of worship.'Contrary to common thought, it was never the intention of the New Urbanists to just make the world a more beautiful and more genteel place to live, but more importantly one in which to awaken in the citizen the realization that in a democratic society he or she has an obligation to act civilly and contribute to a nexus of social, political and economic forces. Nowhere is this more evidenced than in the fact that the movement today is led not by an architect per se but by the former mayor of Milwaukee, John Norquist, a politician who in invoking the virtues of New Urbanism almost always does so in light of its propensity for economic yields. In an interview with ECOBUILDING, an online subsidiary publication of the AIA, he says ' $[\mathrm{w}]$ e really don't need to create (economic) incentives, so much as we need to allow urbanism to be unleashed...' and this to allow cities to acquire 'economic vitality and livability.'

The new Urbanists donot show signs of ebbing; their membership seems to grow every year. For now at least part of the future of the city belongs to them. But there are other futures in the work, some well under way, others still in the realm of construction and may be more science fiction at this point than otherwise. We cannot talk about the future of the city without talking about them. Technology - digital, biological and otherwise - is truly and structurally changing the way we navigate and understand reality, including the way we understand the role of parenthood and its traditional sovereignty over citizenship and nationality.

\section{THE CITY AS SCAFFOLDING FOR DATA HARVESTING}

One of the more fascinating stories to emerge in the wake of such technological advances is the notion that the city is a carcass of its old self, an empty vessel, good only as a scaffolding from which to suspend the instruments of 21 st century surveillance networks. Now that the functions of the city have been displaced and de-centred, from real space to the virtual, including engaging the traditional and central function of the city as the seat of governance, the city offers itself up as a data centre, constantly observing, recording and monitoring the flow of information. In an essay culled from a forthcoming book on soft cities, the author aptly asks the following question: 'How much of what 
we call a city is still embodied in streets and buildings, parks and squares?' [5] His wager is not much for much of the city has been absorbed by digital networks and disseminated across the waves. 'Let's start with my studio,' he says.

'I inhabit two architectures, more or less alien to each other - an information architecture, and a physical one. My office is a notebook computer that weighs less than seven pounds, and I carry it with me when I travel; my storage 'space' is on data servers in Germany.'

The author talks about soft cities, not as constructs whose buildings and infrastructure are pliable per se, but as centres run by 'soft' ware and intelligence electronic systems that harvest and distribute information. 'A city is "soft",' he says,

'to the extent that it can be characterized as a meta-network of data flows and personal communication, operating to some extent independently of the "hard" infrastructure of buildings and roads...In the new soft city, people are offered "awareness," governments obtain "intelligence," and planners, architects and engineers get lots of rich new "data mines" [5].

Each piece of information obtained in this soft city may or may not be of any value alone but when correlated against other data can begin to acquire economic and social worth and generally work to help the health and wellbeing of place. Information about traffic flow on a particular street in the city may be useless on its own but when correlated with, say, ticket sales for a game across town may yield good information about the use of parking spaces in the city, which in turn can be used to make wise and timely decisions about what to do with those spaces, how to purpose them properly. Writing in Foreign Affairs, Kenneth Cukier Viktor Mayer-Schoenberger say that shifting the focus from causation to correlation 'represents a move away from always trying to understand the deeper reasons behind how the world works to simply learning about an association among phenomenon and using that to get things done' [6].

One thing that the soft city can do that architects have not been able to do quite well is give hard facts about the worth of aesthetic, a topic notoriously difficult to defend economically and otherwise and which has been relegated to the annals of philosophy alone. Asked about the role of architectural beauty in the city, the economist Paul Romer told the urban issues writer Greg Lindsay in Forefront 'It's important that buildings don't catch fire or fall down when there's an earthquake. Otherwise, I don't think it matters all that much' [7]. Hard data obtained from sensors and camera on the one hand and cash registers and hotel receipts on the other, along with perhaps police records and hospital admissions could dispel such cold assessment of aesthetics and yield information that gives expression traction and prove that a beautiful place is also an economically and physically healthy environment to be. Other areas of focus where aesthetics is rarely appreciated or equated with good results is schools: harvesting data correlating walking information, test scores and absences may just prove that well designed educational facilities, including the way sidewalks are organized and playgrounds structured, represent more than passing visual interest but can in fact impact learning propensity and the general wellbeing of kids and adults alike.

A networked society would have a better sense as to what its place is all about. A picture may be worth a thousand words, but it can also be a lie. It can tell you that a place is alive with people and activity when in fact it is to the contrary. Streaming pictures from other, less desirable, areas of the city would give you a more accurate sense as to how your city may be lopsided and in need of much needed human distribution, potentially spurning people to swarm in that direction and balance things out. A picture can also tell you that city life is achievable, so full of promising new and charming development, when in fact it is not. Cities today are essentially the privilege of the wealthy few, many of whom donot even live in those places. In his book The Next 100 Million, Joel Kotkin lays it out well, simply and succinctly: 'A growing number of apartments [in the city] are owed by nonresidents-in 2007; non-residents made up to $10 \%$ of all Manhattan apartment purchases, up from 5\% 


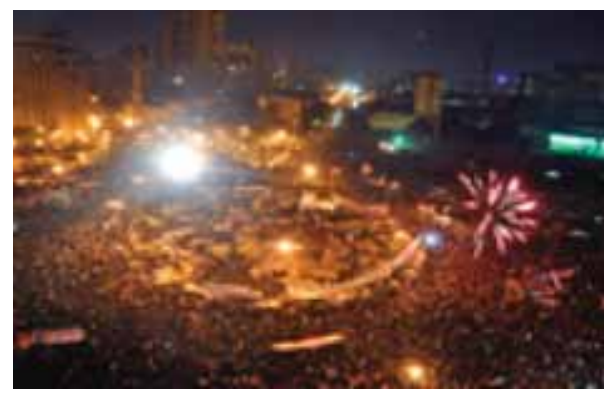

Figure 1: Ground zero of the Arab spring. Image shows celebrations in Tahrir Square shortly after Mubarak's resignation. February 11, 2011. Courtesy of Wikipedia: http://en.wikipedia. org/wiki/File:Tahrir_Square_on_February11.png.

8 years ago....Living in a superstar city...is like owning a scarce luxury good' [8]. Being privy to data of this sort, cross referencing socio economic reality with live pictures of the city would give you a better and healthier psycho geographic sense of your whereabouts, not to mention exposing hoax marketeering schemes for the reality they represent.

One person who is not only using data harvesting to prove the worth of aesthetics but also who is actually doing so to produce it himself is Dan Hill. As a designer and urbanist at ARUP he is interested in turning the invisible flow of data into visible works of art whose essence is to make people aware of what we as a collective society are doing and caring about. It is his belief that society is not likely to act on an issue unless somehow it awakens to the realization that there is indeed a groundswell of support precipitating on behalf of that issue. The Arab Spring is one example out of many that would not have happened without it (Fig. 1). By aggregating data whose message or character is of a similar nature and turning it into art, the idea is to make visible to the public matters that the public already cares about but which it did not know it did, and which would have otherwise remained buried in the sand.

This way the prospects for the future of the city shift from one whose focus lies with the autonomy of the planner armed with formal surveys about land use, demographics and such, to one whose power and indeed authenticity stems from the fact that information gathered on its behalf comes from informal and unselfconscious sources. This could potentially lead to the creative breaking down of the old city divides, established some 100 years ago or so when the city needed some level headed planning to separate functions that were environmentally and socially at odds with each other. Instead of the old city zones, traditionally marked by clear physical separations such as highways, rail tracks and parks, now we might get a city whose character is defined by a diverse and unpredictable flow of people and functions. By giving expression to instantaneous changes in the city, including bringing to light ways of inhabiting parts of the city that had been previously deemed unapproachable, data harvesting could and should refresh the promise of the city for us.

\section{THE SMART CITY}

Rio de Janeiro is not waiting for the future to capitalize on the future of 'soft city.' In 2010 it opened a data centre designed and installed by IBM to calibrate information emerging from various departments and agencies in the city (Fig. 2). Whereas before it took forever to mobilize, say, fire departments and have them respond to an incident across the way in the city, today and with the help of this data centre the two can be connected instantaneously. Here '[v]ideo streams in from subway 


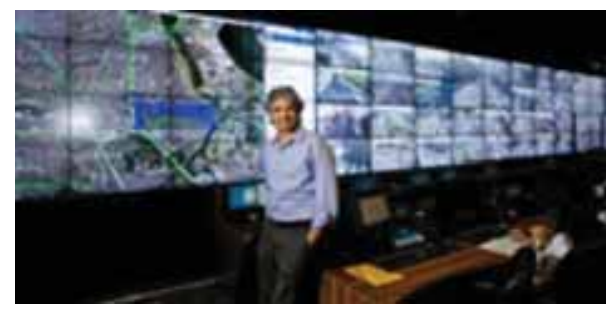

Figure 2: IBM installed Data centre in Rio de Janeiro, coordinating, among other nodes, the various services of the city. Image courtesy of The New York Times.

stations and major intersections...' says a New York Times article, informing engineers and technicians about potential traffic blockages and preparing for dispatches if need be. At a different part of the centre '[a] sophisticated weather program predicts rainfall across the city...' and at yet another '[a] map glows with the locations of car accidents, power failures and other problems' [9]. The objective is 'to collate all this data and...identify patterns and trends...' which to architects and urbanists may say nothing beyond logistics but which upon deeper analysis could suggest that their role in designing the future of the city lies less in mapping out the shape and location of buildings and more in how those buildings tie better with infrastructure or may themselves become infrastructure [10].

A smart city would know how to minimize waste and distribute energy where energy is needed. Trains used to run on a linear logic, going and stopping where stations are located and without recognition of how and when energy is wasted during those times. A new distributed logic has changed all that and is beginning to create a mini revolution in both transportation and energy use. Consider, for instance, the newly invented regenerative breaking system that allows trains 'to recover much of a slowing train's kinetic energy and convert it back to electrical energy' [11]. Some of this energy can be directed to the public grid and used to power homes and factories. Other energy saving inventions in the work include doubling the order of how trains work and supplementing running cabs with platforms that would run alongside the trains, picking passengers along the way and taking them to their desired location in the centre of the city. This way trains, which are hulking energy monstrosities, wouldnot have to stop and discharge energy into the ether; they would keep running and running from beginning to end of day, and therefore minimize waste. 'Local trains,' croons an economist article, 'would use side by side rails to roll alongside intercity trains and allow passengers to switch trains by stepping through docking bays' [11].

\section{THE FUTURE OF THE ENVIRONMENTAL CITY}

To a great extent our interest in the future of the city stems from the environmental revolution of the past 10-15 years, its vigil to ensure that what we build today will sustain a world for future generations to come. A great many new inventions have come around during this period to make that a reality, including improvements in solar harvesting technology, green roof design and energy saving sensors. But many consider these inventions and improvements little more than palliatives with little or no impact on the kind of paradigm shift that is needed to slow down and reverse the methodical destruction of the earth. A whole new 'natural contract' needs to be written, to quote Michel Serres, one that does not bias the social over the natural but which seeks to align the two in lockstep patterns of recognition. Because as he reminds us in The Natural Contract: just as ' $[\mathrm{t}]$ he earth existed without our unimaginable ancestors, [it] could well exist today without us' We, however, 'cannot exist without it' [12]. 
But what could this paradigm shift look like? What would it mean to live by ecological principles and not the social? Serres would say that the answers lie in 'real time,' of living by environmental sensibility in real time and not some delayed version of it. Much of our regard for the environment so far has come in the form of capturing, storing and re-accessing natural energy. He would like us to unfurl that and in a way lose ourselves, at least in periodic episodes, to the forces of nature. Could we calibrate our movements and indeed our sense of success less around the human and more around, say, weather. 'To safeguard the earth or respect the weather, the wind and rain,' he says, 'we would have to think toward the long term, and because we don't live out in weather, we've unlearned how to think in accordance with its rhythms and its scope' [13]. We have to relearn what we have unlearned through the course of civilization.

Only 20 years ago this would have sounded like dream talk but today a good cohort of scientists and designers have joined forces to heed the call. At least part of the future belongs to them. They are biologists and architects, chemists and urbanists, working together to produce environments that ebb and flow much like cells and weather patterns do the same; namely as open systems that are in constant 'communication' with the world around them.

Ecological thinking can mean "'different things to different people,' one writer explains in a book devoted to ecological urbanism, 'but at its essence,' he continues, 'it represents the challenge of establishing a new order in architecture in which there is harmony between people...buildings... cities and the natural world...' [14]. One way of achieving this harmony would be to learn from living systems whose efficiency lies in the manner in which they unselfconsciously and automatically respond to changes in the environment. 'All living creatures-from the simplest to single cell organism to humans-have evolved ways to change their shape and function, and thereby optimize their performance in response to environmental cues...' Buildings can do the same or at least acquire the organic technology that would allow them to breath and flex and ultimately adapt to the environmental forces changing around them. This could mean infusing in the very infrastructure of architecture - its walls, floors and windows - plant life that would either help remediate polluted air or capture wind and hydro energy. 'Imagine buildings covered with layers of small lenses that mimic how sea creatures concentrate light deep under the sea, but these illuminate photovoltaic cells or living bacteria that have been genetically reprogrammed to convert into energy' [14].

An article published in Architectural Design devoted to this subject speaks of leveraging biology to advance what its author calls 'Neoplasmatic' design. Its claims are pretty ambitious, calling for a hybridization of the built environment, half physical half biological, in which buildings serve as prosthetic devices by which to replace old severed and sick parts of the city with new environments but also act as living systems that would amplify the potential of architecture to regulate and navigate diverse conditions. A student at the Bartlett school of design is shown exploring a bio-mechanical hybrid plant species whose job is or would be to act as biomechanical sensor mechanism in the natural environment, detecting and responding to environmental changes such as pollution in air or water...' [15]. Other projects of a similar ilk can be seen demonstrated by Philip Beesley's Hylozoic Ground, a geotextile construct capitalizing on advances in nano-technology whose 'fronds and whiskers' serve as antennas gathering air born particles and turning them into 'hylozoic' soil [16].

The computational version of the biologic is the parametric. Rather than let biological plant life encode an automatic responses to the environment, the parametric logic let's scripting do the leg work. It starts with inputting a set of data, environmental and social, around which the final form should be fashioned and the computer will fashion it for you. Because the intention and indeed the objective is to make for an optimal correlation between things like weather and social surveys, on the one hand, and city and architectural shape, on the other, the result resemble nothing of the old urban design ways, in which geometry and set proportions determined what goes and what stays and 
how things look. Rather now things look much softer, more curvy, and for the lack of better words, more organic and dynamic. Note the design of a new wind mill by Nigel Young/Foster and Partners; instead of the standard pole that we have come to know the windmill by, setting it apart from the built environment, here we see this piece of marvellous environmental technology integrated into the building, parametrically shaped so that together - building and mill - can generate the most optimal energy production possible (Fig. 3).

Patrik Schumacher, an advocate and defender of Parametricism, chooses the word malleable and sees parametric architectural forms as 'malleable components' working together in a 'play of mutual responsiveness as well as contextual adaptation.' This would lead to 'an overall intensification of relations that gives the urban field a performative density, informational richness, and cognitive coherence that makes for good legibility...' [17].

Much of this stems from distributive logic in which things are less governed by a central authority and more understood as a function of distributed information. In a networked and biological society, reality is defined by evolutionary principles, in which things or cells, if you will, grow not because there is a command centre issuing demands and directions but because of an inherent self-organizing drive to keep watch and adapt every step of the way. Systems and logics of this sort cannot by nature make big and sudden changes but incremental ones and always not out of speculation but out of a careful assessment of need. Some of these increments may be bigger than others and they may scale downward or upward, which for architecture and cities amounts to a game change in the way plans are drawn, namely as determined by a fixed pattern. Now height, distance and block-size are not determined by a standardized urban code but by a set of non-human and selflessly scripted parameters (Fig. 4).

Moreover, much like a swarm whose members operate independent of each other but who in the final picture unselfconsciously come together to create a unified whole and achieve some higher end, so are these parametric city increments; each works as an autonomous piece, reacting 'individually according to internal rules and the state of [their] local environment' [18]. Should one increment fail the next picks up the slack and carries the collective along until the deficiency is fixed and the health of the unit is restored.

One could reverse the order and instead of feeding the computational model parametric conditions, which follow a top down logic, working with big picture environmental parameters, now feed it with bottom up information, data such as those stemming from household use, waste and other interactive functions. Rather than model and construct a world based on a response to the environment, this way we would do so based on a cellular logic, supplying the unit with enough intelligence so as to naturally and automatically give birth to the next cell over whenever that growth is ready and forthright (Fig. 5).

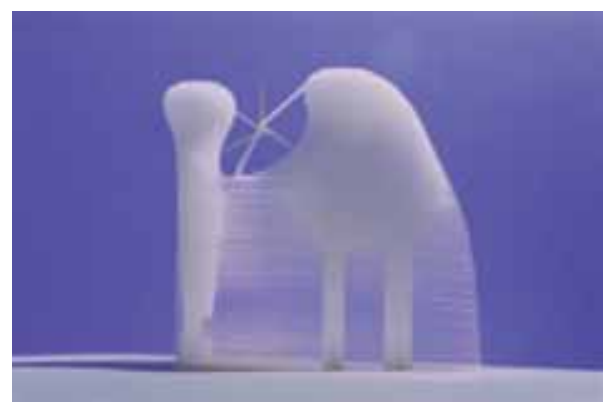

Figure 3: Ventiform model, courtesy of Nigel Young/Foster + Partners. 


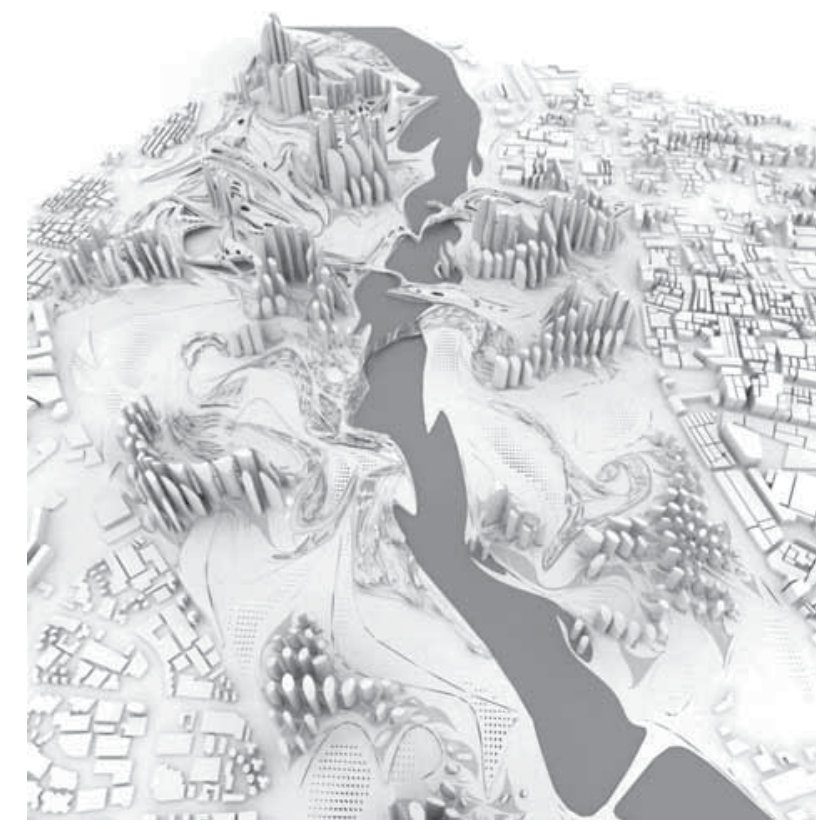

Figure 4: A parametric city ebbing and flowing contrary to prior Cartesian and hierarchical planning. Image courtesy of Subharthi Guha: Zaha Haddid Architects.

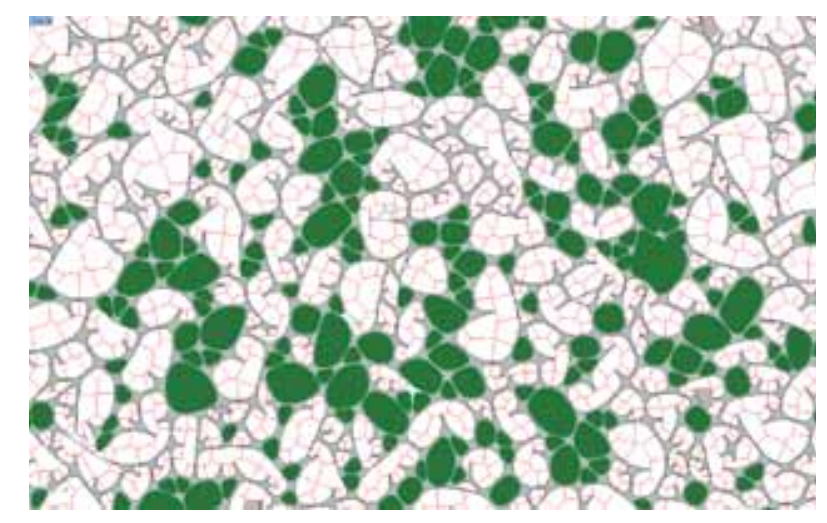

Figure 5: Biological bottom up computational modelling, building on collective intelligence. Courtesy of Subharthi Guha: Zaha Haddid Architects.

\section{CONCLUSION}

About 100 years ago the American city was a crazy mess. It had just seen a dramatic influx of people from the rural countryside but also from other parts of the world. Industry was rising and with it squalid neighbourhoods, homelessness, unsanitary conditions and much more. Architects and planners, from Ebenezer Howard to John Nolen and others wanted to do something about the matter. They drew diagrams, wrote books and devised schemes that sought to organize but also sanitize the functions of the city. To be sure their projects did not stem in isolation or mature out of thin air but were themselves the outcome of disciplinary action by the state over the previous 200 years. 'Since 
the eighteenth century,'explains Matthew Gandy in a recent book on Posthuman Territories, 'the human body has become progressively incorporated into a nexus of architecturally and regulatory structures to produce a new spatial order in the modern city' [19]. The modernists charge may have very well continued in this vein into the future had it not been for two key developments: the first having to do with the precipitous change in concern over the environment; the other with the sudden and exponential rise of advancement in computational technology. Together they brought an inevitable call to see beyond the human and create environs where human and machine intelligences co-exist in varying degrees of interdependencies. This of course cannot proceed without its own self organizing critical vigilance.

\section{REFERENCES}

[1] Dolores H., Building Suburbia, Vintage Books: New York, 2003.

[2] Christine B., Dreaming the Rational City, MIT Press: Cambridge, MA, 1990.

[3] Both of these theoreticians wrote essays/books with the word "tomorrow" in their titles: Howard "The Garden Cities of Tomorrow" and Le Corbusier "The City of Tomorrow".

[4] William W., The Social Life of Small Urban Spaces, The Conservation Foundation: Washington, DC, p. 24, 1980.

[5] Skelton, C., "Who's Your Data?" Adopted from the author's forthcoming book New Soft City Culture: The Case of Betaville.

[6] Kenneth C. \& Mayer-Schoenburger, V., The rise of big data. Foreign Affairs, p. 32, May/June 2013.

[7] Kelly C., Architects Versus Economists: The Battle for the Future of Urbanism, From Honduras to Upstate New York, BLOIUN ARTINFO, available at http://www.blouinartinfo.com/ news/story/804804/architects-versus-economists-the-battle-for-the-future-of-urbanism-fromhonduras-to-upstate-new-york, 18 May 2012.

[8] Joel K., The Next Hundred Million: America in 2050, Penguin Books: New York, p. 55, 2010.

[9] Singer N., Mission control, built for cities. The New York Times, March 3, 2012.

[10] For more visionary insight as to how architecture and infrastructure may coalesce, see the work of UN Studio.

[11] "Ideas coming down the track," The Economist, p. 13, June 1st-7th, 2013.

[12] Serres, M., The Natural Contract, The University of Michigan Press: Ann Arbor, p. 67, 1995.

[13] Ibid, p. 29.

[14] Ingber D., Ecological Urbansim, eds. M. Mostafavi \& G. Doherty, Lars Muller Publishers: Baden p. 308, 2009.

[15] Mina ala Jaaski in Marcos Cruz and Steve Pike article, Neoplasmatic design. Architectural Design, "Digital Cities", p. 81, August 2009.

[16] Harrison A.L. (ed.), Architectural Theories of the Environment: Posthuman Territories, Routledge: New York, 2013.

[17] Schumacher P., The parametric City, Zaha Hadid - Recent Projects, A.D.A. Edita, Tokyo, 2010.

[18] Kelly K., Out of Control, Addison-Wesley Publishing Co.: New York, p. 22, 1994.

[19] Harrison A.L. (ed.), Architectural Theories of the Environment: Posthuman Territories, Routledge: New York, p. 216, 2013. 